\title{
ІНЖИНІРИНГО-МАРКЕТИНГОВИЙ ЦЕНТР ІННОВАЦІЙНИХ ТЕХНОЛОГІЙ ЯК ОСНОВА АКТИВІЗАЦІЇ ІННОВАЦІЙНО- ІНВЕСТИЦИЙНОГО ПОТЕНЦІАЛУ ПІДПРИЕМСТВ ЗАЛІЗНИЧНОГО ТРАНСПОРТУ
}

\author{
Дикань В.Л., д.е.н., професор, \\ Соломніков I.В., аспірант (УкрДУЗТ)
}

\begin{abstract}
Стаття присвячена обгрунтуванню доцільності забезпечення трансферту технологій на основі впровадження інжинірингу. Досліджено особливості промислового інжинірингу, визначено його переваги. Запропоновано створення Інжиніринго-маркетингового иентру інноваџійних технологій, діяльність якого направлена на розробку та впровадження інноваційних технологій, трансферт інновацій, надання технологічних, інформаційних, консультативних послуг, щзо дозволить провести модернізачію підприємств залізничного транспорту, забезпечити їх техніко-технологічний розвиток.
\end{abstract}

Ключові слова: інновації, інноваційно-інвестиційна діяльність, інжниніринг, науково-технічний потенціал, техніко-технологічний розвиток, підприємства залізничного транспорту.

\section{ИНЖИНИРИНГО-МАРКЕТИНГОВЫЙ ЦЕНТР ИННОВАЦИОННЫХ ТЕХНОЛОГИЙ КАК ОСНОВА АКТИВИЗАЦИИ ИННОВАЦИОННО-ИНВЕСТИЦИОННОГО ПОТЕНЦИАЛА ПРЕДПРИЯТИЙ ЖЕЛЕЗНОДОРОЖНОГО ТРАНСПОРТА}

\author{
Дикань В. Л., д.э.н., профессор, \\ Соломников И.В., аспирант (УкрГУЖТ)
}

\begin{abstract}
Статья посвящена обоснованию иелесообразности обеспечения трансферта технологий на основе внедрения инжиниринга. Исследовань особенности промышленного инжиниринга, определены его преимущества. Предложено создание инжиниринго-маркетингового иентра инновачионных технологий, деятельность которого направлена на разработку и внедрение инновачионных технологий, трансферт инноваций, предоставление технологических, информационных, консультативных услуг, что позволит провести модернизацию предприятий железнодорожного транспорта, обеспечить их технико-технологическое развитие.

Ключевые слова: инновации, инновационно-инвестиционная деятельность, инжиниринг, научно-технический потенциал, технико-технологическое развитие, предприятия железнодорожного транспорта.
\end{abstract}

(C) Дикань В.Л., Соломніков I.B,

Вісник економіки транспорту і промисловості № 57, 2017 


\title{
ENGINEERING-MARKETING CENTER FOR INNOVATIVE TECHNOLOGIES AS THE BASIS ENHANCING INNOVATION AND INVESTMENT POTENTIAL OF RAIL TRANSPORT
}

\author{
Dykan V.L., Doctor of Economics, Professor, \\ Solomnikov I.V., postgraduate (USURT)
}

Article feasibility studies dedicated to providing technology transfer through the introduction of engineering. The features of industrial engineering, defined its advantages. A creation of Engineering and marketing of innovative technologies center (EMITC), whose activities are focused on the development and implementation of innovative technologies, transfer of innovation, providing technical, informational, advisory services, which will allow to modernize railway undertakings to provide their technical and technological development.

The main objective of EMITC should determine the development of technological solutions for railways, railway undertakings and other customers, as opposed to industrial projects aimed at the production and sale of the final product uniform, which includes technical, technological, organizational and managerial innovation.

An important objective of the Center is to involve engineering of rail transport in the implementation of innovation by combining manufacturing, scientific and technological capabilities, lower costs for scientific research and development, the introduction of advanced technology and equipment, according to the requirements of today's market, the commercialization and development held their introduction into the production process and production.

He plays the role of coordinator of technological development and modernization, including the solution of such problems as the unification of the purchased equipment, reduce maintenance costs.

Keywords: innovation, innovation and investment, engineering, scientific and technical potential, technical and technological development of rail transportation.

\section{Постановка}

Загальновідомо, що запорукою стійкого економічного та техніко-технологічного розвитку підприємства $є$ створення та впровадження інновацій, які є результатом реалізації інноваційно-інвестиційного потенціалу підприємства та сприяють підвищенню технологічного рівня підприємств, технологічних укладів, впливають на продуктивність праці, витрати на виробництво та $є$ результатом дії науково-технічного прогресу.

Інноваційно-інвестиційний

потенціал підприємств залізничного транспорту, зокрема ПАТ «Українська залізниця», формується на основі результатів функціонування таких підприємств, як Дніпрзалізничпроект, Львівтранспроект, Одеськзалізничпроект,

\begin{abstract}
Укрзалізничпроект, філія «Науководослідний та конструкторськотехнологічний інститут залізничного транспорту». Кожне підприємство виконує розробку інноваційно-технологічних проектів щодо розвитку залізничного транспорту за окремим напрямом. Однак, відсутність співпраці між науковими та виробничими підприємствами залізничного транспорту не дозволяють отримати синергетичний ефект від їх діяльності та вирішити проблеми галузі, які обумовлюють кризовий стан залізничного транспорту, високий рівень зносу основних виробничих фондів, використання застарілих технологій виробництва та перевезень.
\end{abstract}

В сучасних умовах, коли пріоритетними напрямами розвитку в

Вісник економіки транспорту і промисловості № 57, 2017 
економіці $\epsilon$ саме інноваційний розвиток, вирішення зазначених проблем доцільно досягати за рахунок інтеграції виробництва, науки, науково-технічного потенціалу галузі та країни, забезпечення трансферту технологій, імплементації нововведень у виробництво, що потребує впровадження інжинірингу та формування організаційноекономічної структури, яка забезпечить взаємодію, координацію діяльності підприємств залізничного транспорту, задіяних в процесі створення та впровадження інноваційних технологій.

Активна взаємодія підприємств залізничного транспорту 3 науководослідними організаціями створює умови для ефективної реалізації досягнень науково-технічного прогресу та забезпечення конкурентоспроможності підприємств. Використання новітніх технологій, нових видів продукції створює для підприємств залізничного транспорту не лише основу довгострокової конкурентної стратегії, задоволення нових потреб споживачів транспортних послуг, а і підсилює ринкові позиції за рахунок комерційного використання інновацій.

Аналіз останніх досліджень. Питаннями впровадження інноваційних проектів в виробництво, розвитку інноваційних підприємств, розвитку інжинірингових послуг, створення інжинірингових центрів та компаній присвячені роботи Арсанова В.А., Грибовського А.В., Зайцева О.В., Краскевич В.С., Кудашова B.I, Пищало К.О., Лифанова .Д., Шинкевича О.І., Ситник О. Б., Чекмачева І.Ю., Іоди О.В. та ін. [11-18].

Проблемам розвитку інноваційної діяльності підприємств залізничного транспорту, переходу їх на інноваційний шлях розвитку, в тому числі, i за рахунок формування інтегрованих структур, інноваційно-логістичних центрів, кластерів, які сприяють акумулюванню інноваційного, потенціалу

присвячена

вітчизняних

залізничного транспорту велика кількість робіт вчених, серед яких: Дикань В.Л., Зубенко В.О., Калініченко Л.Л., Корінь М.В., Назаренко І.Л., Полякова О.М., Толстова А.В. та ін. [1-10].

Однак, в сучасних умовах господарювання перед підприємствами залізничного транспорту виникає необхідність забезпечення технікотехнологічного розвитку шляхом трансферту інновацій, інтеграції науки та виробництва на основі впровадження інжинірингу.

Метою статті $\epsilon$ обгрунтування доцільності створення та основні аспекти функціонування Інжинірингомаркетингового центру інноваційних технологій, як ключового інструменту активізації інноваційно-інвестиційного потенціалу та забезпечення технікотехнологічного розвитку підприємств залізничного транспорту.

Виклад основного матеріалу. Впровадження нових технологій на підприємствах залізничного транспорту можливо при збалансованому розвитку всіх елементів виробничого ланцюжка інноваційної продукції: від наукових досліджень до виробництва продуктів на основі нової технології. Передача технології (результатів НДР і ДКР) має на увазі передачу специфічної інформації, що стосується регламентів виробництва, опису технологічних процесів, необхідного технологічного та допоміжного обладнання для цілей замовника; проектування, створення i передачі в експлуатацію виробничого обладнання для запуску нових i модернізованих виробничих ліній по заданих параметрах завершують передачу технології [18].

Найважливішими параметрами технологічного процесу стають інженернотехнічне забезпечення запуску виробництва інноваційних продуктів i оперативність впровадження технологічних рішень. При цьому інноваційні технології 
ускладнюються, набуваючи системний, все більш комплексний характер, що, в свою чергу, обумовлює необхідність забезпечення процесу передачі нових технологій у виробництво. Цього можливо досягти за рахунок впровадження промислового інжинірингу.

$$
\text { Інжиніринг }
$$

безпосередньо пов'язаний 3 процесами впровадження інновацій та $є$ невід'ємною частиною модернізації підприємств залізничного транспорту, їх техніко-технологічного розвитку. Він $є$ комплексом взаємопов'язаних робіт і послуг технічного, фінансового, юридичного і організаційного характеру, спрямованих на створення або модернізацію підприємств та інфраструктурних об'єктів, що забезпечують ефективне повернення інвестицій [14].

Швидкість і якість інжинірингу приносять додаткові конкурентні переваги, забезпечуючи необхідний економічний ефект від впровадження нової технології, масштабованості i оптимізації технологічних процесів.

Промисловий

передбачає застосування загальних принципів інжинірингу, наукового менеджменту, а також методів та моделей різноманітних наукових дисциплін для забезпечення і підтримки високого рівня виробництва i рентабельності сучасних підприємств. Зрозуміло, що ефективне функціонування підприємства включає проектування i створення виробничих потужностей, ефективне використання людських ресурсів, забезпечення безпеки виробничої діяльності, контроль якості і т. ін. Виробничі методи і технології, засоби автоматизації, статистика, вивчення операцій, взаємодія людських ресурсів і машин $\epsilon$ невід'ємними частинами сучасного промислового інжинірингу. Промисловий інжиніринг тісно пов'язаний 3 сучасними методами управління [17].

До складу найважливіших переваг системи інжинірингу слід віднести:
- підвищення при інших рівних умовах ефективності інвестицій у зв'язку із появою реальних важелів впливу на бюджет проекту;

- скорочення термінів виконання робіт і виробничих витрат;

- привабливість для замовників перспективи консолідації в одних руках необхідного набору послуг, пов'язаних із здійсненням інвестиційного проекту;

поява реальних передумов для переходу до ефективного професіонального управління у зв'язку 3 зосередженням в руках інжинірингової компанії технічної i вартісної інформації по проекту;

- зниження інвестиційних і інших ризиків для підприємства, яке використовує систему інжинірингу;

- підвищення

конкурентоспроможності на вітчизняному $\mathrm{i}$ іноземному ринках у зв'язку з визнанням діловим світом ефективності використання інжинірингу.

Впровадження інжинірингу на ПАТ «Українська залізниця» та підприємствах залізничного транспорту дозволить активізувати інноваційну та інвестиційну діяльність підприємств, створити ефективний механізм розвитку їх інноваційно-інвестиційного потенціалу. Крім того, забезпечення підприємств залізничного транспорту інноваційними технологіями, належним рівнем технікотехнологічного розвитку, оновлення підприємств, на нашу думку, доцільно здійснювати шляхом формування Інжиніринго-маркетингового центру інноваційних технологій (IМЦІТ), який $є$ інноваційним підприємством та повинен входити до складу ПАТ «Українська залізниця». Основними сферами діяльності центру $\epsilon$ розробка на замовлення регіональних філій ПАТ «Українська залізниця», підприємств залізничного транспорту та промислових підприємств транспортного машинобудування оригінальних технологій, обладнання та інноваційних продуктів на основі наявної 
технологічної бази (базової технології), модернізація підприємств, надання технологічних, інформаційних, консультативних та інших послуг по забезпеченню інноваційно-інвестиційної та господарської діяльності, комерціалізація результатів їх науково-технічної діяльності та післяпродажний супровід інноваційних технологій та продуктів.

Головною метою функціонування ІМЦІТ слід визначити розробку технологічних рішень для залізниць, підприємств залізничного транспорту та інших замовників, на відміну від виробничих проектів, націлених на виробництво i реалізацію кінцевої уніфікованої продукції, до якої належать технічні, технологічні, організаційні та управлінські інновації.

Основними цілями діяльності

IMЦІТ є:

1. Підвищення технологічної готовності підприємств залізничного транспорту шляхом оптимізації процесу розробок, виробництва i впровадження передових технологій i технологічного обладнання для комплексного вирішення завдань модернізації i технологічного розвитку (переозброєння) підприємств залізничного транспорту за рахунок:

- створення нових вітчизняних інноваційних технологій, реінновацій;

- систематизації імпорту передових технологій провідних світових виробників і реверсивного інжинірингу.

2. Підвищення ефективності інвестицій за напрямками модернізації i технологічного розвитку підприємств, забезпечення взаємодії 3 підприємств залізничного транспорту 3 фінансовими інститутами.

3. Комплексне сприяння інноваційному розвитку не лише підприємств залізничного транспорту, а i підприємств споріднених галузей, зокрема транспортного машинобудування.

Важливим завданням центру $\epsilon$ залучення підприємств залізничного транспорту в процес реалізації інновацій за рахунок об'єднання виробничого і науковотехнічного потенціалу, зниження витрат на проведення наукових розробок i досліджень, впровадження передових технологій і устаткування, відповідно до вимог сучасного ринку, комерціалізація проведених розробок і впровадження їх у виробничий процес та виробництво.

До основних завдань ІМЦІТ слід віднести:

1) організацію інформаційноаналітичної діяльності в сфері високих технологій, включаючи дослідження ринкових тенденцій, інноваційних напрямків i проектів, рейтингування світових виробників технологічного обладнання і т.п .;

2) співпрацю 3 профільними ВНЗ в напрямках:

- залучення нових механізмів постійного оновлення інноваційної матеріальної бази, що забезпечує випереджальну підготовку і перепідготовку фахівців;

- підвищення рівня знань професорсько-викладацького складу на основі розробки та впровадження нових рішень, технологій та обладнання;

- розробки і практичної реалізації для підприємств сучасних ефективних технологічних, інноваційних, організаційних та управлінських рішень;

- підвищення рівня наукових розробок на основі нових знань в галузі транспорту та транспортного машинобудування та супутніх галузей, які забезпечують нові можливості розширення спектра НДР, ДКР, затребуваних на підприємствах залізничного транспорту;

3) виконання НДР, ДКР та реалізація їх результатів, надання послуг 3 виготовлення дослідних зразків і малих серій інноваційного продукту, проведення контролю i випробувань інноваційного продукту; 
4) сприяння організації трансферу i комерціалізації технологій в Україні та країнах СОТ;

5) проведення

експертиз

поточного стану, прогнозування розвитку підприємств залізничного транспорту i розробку планів їх модернізації;

6) рекламно-інформаційну

діяльність (включаючи виставкову) за профілем спеціалізації центру;

7) організацію навчання різних категорій персоналу;

8) інжинірингове забезпечення обладнання, що постачається, включаючи проектний інжиніринг (технологічна частина проекту будівництва або реконструкції виробничих підрозділів чи об'єктів).

Механізм функціонування центру, взаємозв'язки учасників процесу трансферту інноваційних технологій представлено на рис.1.

Основою функціонування центру $\epsilon$ команда фахівців, що володіють необхідними компетенціями та мають досвід роботи в даній галузі з провідними промисловими підприємствами, в тому числі і світового рівня. Ця команда фахівців в ідеальній ситуації повинна мати для своєчасного і якісного вирішення проблеми необхідні ресурси: інтелектуальні (фахівці, готові підключитися до вирішення проблеми, основне питання на даному етапі - наявність і комунікабельність команди); матеріально-технічні (програмне і апаратне забезпечення, високі технології, ноу-хау, експериментальне обладнання, спеціалізовані приміщення і т.д.) [15].

3 наявних ресурсів фахівцями формується спеціалізований технологічний ланцюжок, в рамках якого будуть вирішуватися проблеми технікотехнологічного, організаційного, управлінського характеру. У процесі вирішення проблеми відбувається генерування нових знань, їх формалізація та акумулювання, синергетична взаємодія і неформальна передача (трансфер) знань в рамках спільної роботи, розвиток компетенцій i технологій, i в кінцевому підсумку - міжгалузевий трансфер технологій, знань, компетенцій.

Інжинірингово-маркетинговий центр інноваційних технологій об'єднує в собі інтелектуальний, інноваційний потенціали підприємств залізничного транспорту, занятих в науковій діяльності (Дніпрзалізничпроект, Львівтранспроект, Одеськзалізничпроект, Укрзалізнич-проект, філія «Науково-дослідний та конструкторсько-технологічний інститут залізничного транспорту» та інші), профільні вищі навчальні заклади (Український державний університет залізничного транспорту, Дніпропетровський національний університет залізничного транспорту, професійно-технічні навчальні заклади ), науково-дослідні та науково-виробничі підприємства транспортного машинобудування, промислових підприємств суміжних галузей), виробничий потенціал підприємств залізничного транспорту що входять до складу ПАТ «Українська залізниця», вагонобудівних підприємств, промислових підприємств залізничного транспорту (Крюковський вагонобудівний завод, Стахановський вагонобудівний завод, Львівський локомотиворемонтний завод, Тепловозоремонтний завод та інші підприємства).

Технологічним, науковим, дослідницьким ядром інжинірингового центру повинні стати ресурсні центри та лабораторії, які в загальній сукупності сформують мережу центрів колективного користування унікальними науковими розробками, обладнанням. Це база, яка визначає інженерні можливості центру, спектр інжинірингових послуг, спрямованих на розробку рішень, які центр надає в процесі виконання інжинірингових замовлень, проектів, завдань (рис.2.). 


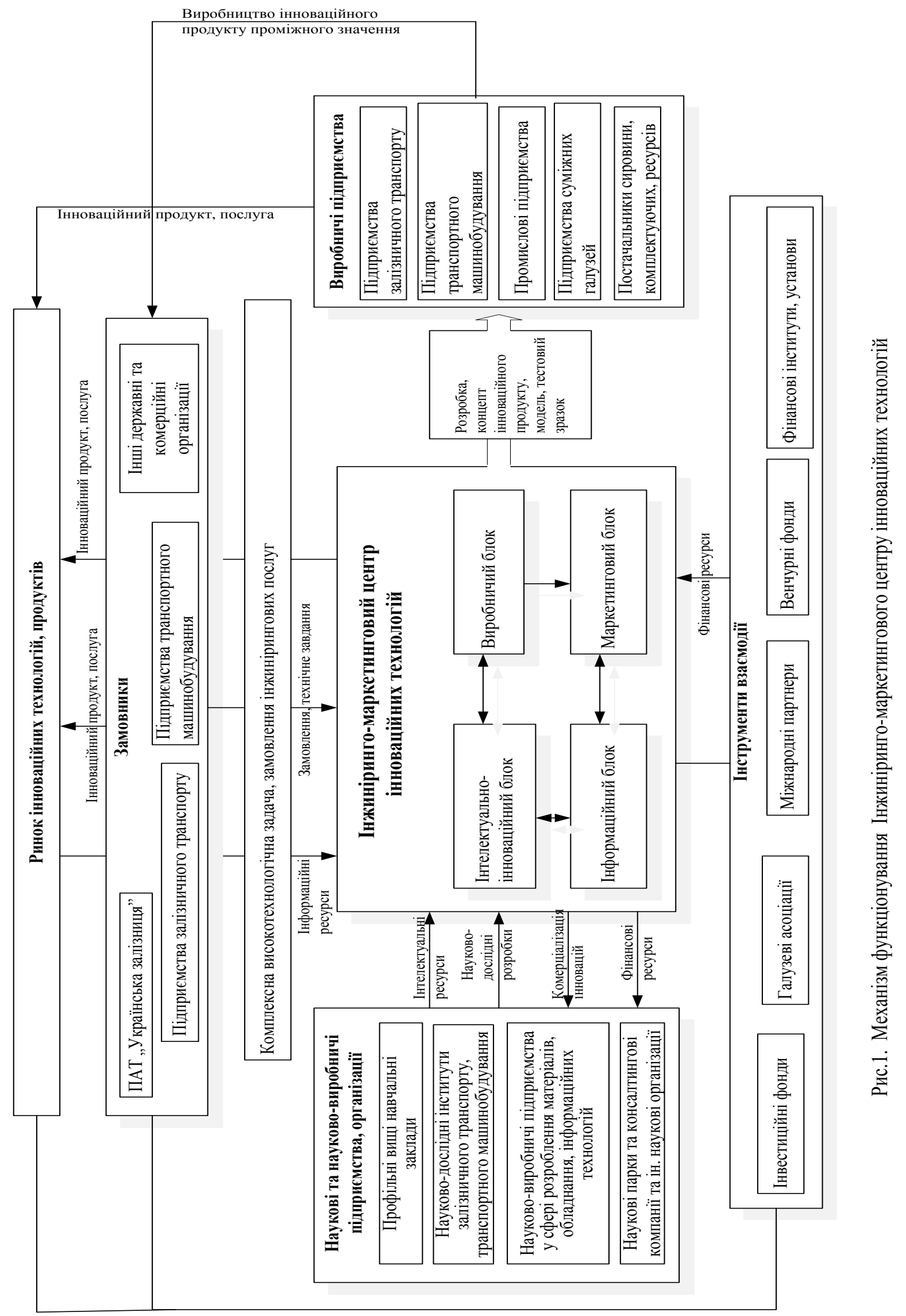




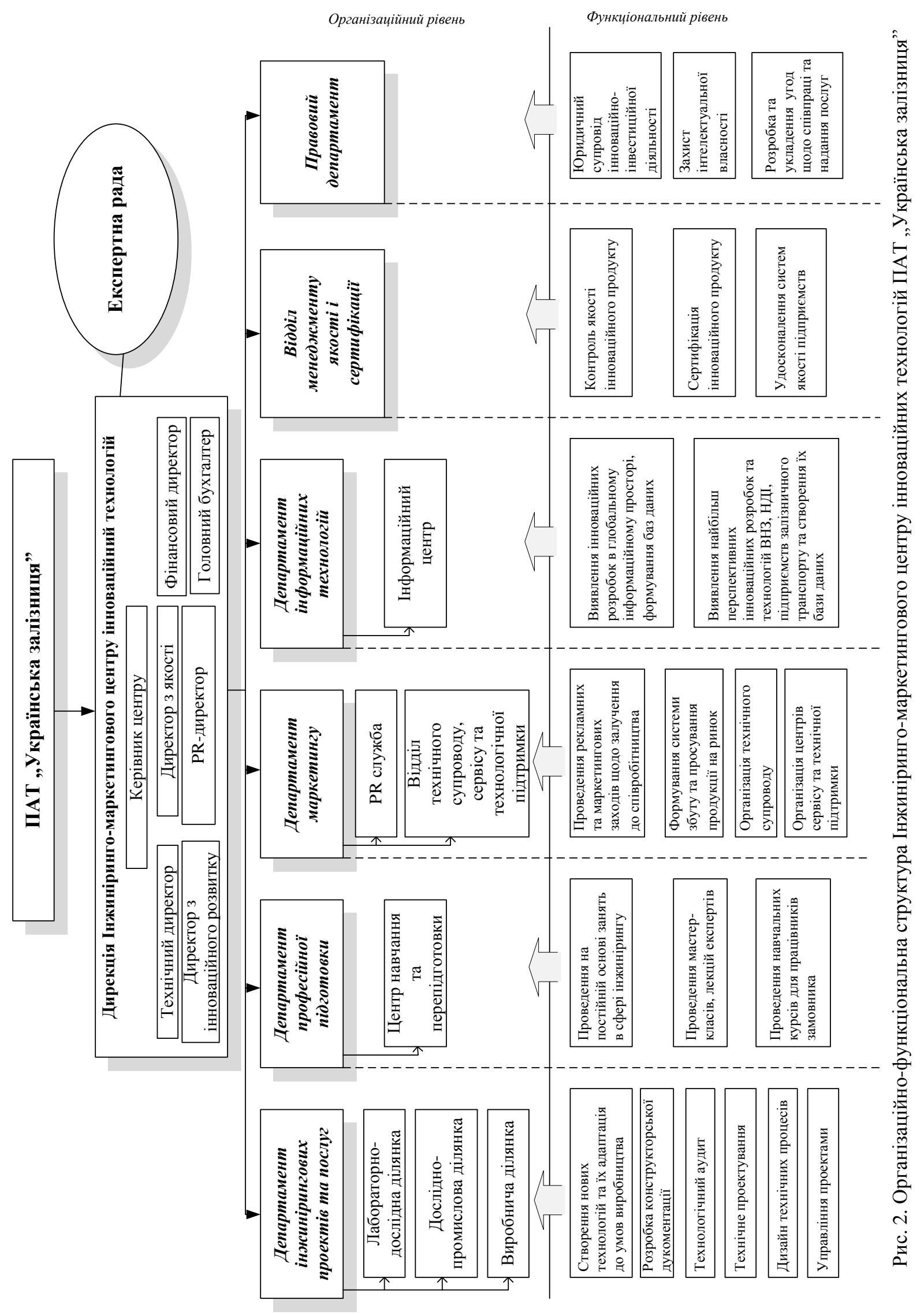

Вісник економіки транспорту і промисловості № 57, 2017 
Координацію та загальне управління центром здійснює дирекція інжинірингового центру. До складу дирекції можуть входити сектор інжинірингових проектів і послуг (займається формуванням замовлень, проектних груп i виконанням інжинірингових проектів), сектор професійної підготовки (здійснює розвиток центру як освітнього майданчика), сектор маркетингу (стимулювання створення інноваційного продукту та його реалізація), сектор інформаційного забезпечення виконання інжинірингових проектів, сектор контролю якості (здійснює контроль якості, сертифікацію продукції) і правової сектор (здійснює юридичний супровід інноваційно-інвестиційної діяльності).

Дирекція розробляє стратегію розвитку інжиніринг-маркетингового центру і здійснює іiі реалізацію за своїми напрямками, координуючи діяльність ресурсних центрів, проектних груп і інших підрозділів центру. Також формує експертну раду, що складається 3 числа провідних вчених, представників ПАТ «Українська залізниця», підприємств залізничного транспорту, представників уряду та громадських організацій, які беруть участь в розробці стратегії розвитку центру, здійснюючи надалі участь у створенні, реалізації та експертизі проектів (наукової, технічної, комерційної та фінансової), координацію діяльності Центру інжинірингу, громадську підтримку i networking (налагодження відносин, створення зв'язків) [18].

Функціональна структура Центру створюється $з$ урахуванням оптимального забезпечення виконання завдань, реалізованого у вигляді комплексу пропонованих послуг відповідно до його департаментів. Результатом діяльності Інжинірингово-маркетингового центру інноваційних технологій в блоці інжинірингових робіт є:
- конструкторська документація на виготовлення технологічного обладнання та систем, в т.ч. 3 метою модернізації існуючих виробничих ліній;

- промислові зразки технологічного обладнання та систем, необхідних для реалізації технологічного рішення;

- технологічна документація на виробничий процес 3 виготовлення продукції, експлуатаційна i ремонтна документація;

- досвідчені і контрольні партії продукції;

- сервіс по монтажу, обслуговування і ремонту розробленого виробничого обладнання;

- сертифікати відповідності виробничого процесу, обладнання необхідним нормам;

- необхідні ОЕМ-компоненти i системи, конструкторська документація на їх виготовлення.

Таким чином, ІМЦІТ в процесі своєї діяльності виконує наступні функції:

- техніко-економічна експертиза можливих рішень для замовника (технологічний аудит);

- виконання проектно-дослідних робіт, формування технічних умов для інтеграції технологічного рішення в виробничий процес;

- виготовлення дослідноекспериментальних зразків, і доведення їх до стадії промислового освоєння;

- технічне проектування;

- дизайн технологічних процесів;

- створення i управління інтелектуальною власністю;

- управління внутрішнім проектом;

- у управління проектом

впровадження та запуску в експлуатацію на стороні замовника;

- розробка конструкторської документації.

організаційно-технологічна підтримка підготовки виробництва при створенні, модернізації виробництв; 
- налагодження та освоєння технічних процесів, обгрунтування вибору необхідного обладнання та оснащення, сировини, матеріалів і компоненті;

- комерціалізація інноваційних технологій;

- проведення маркетингових заходів щодо залучення організацій до співпраці та реалізації інноваційних технологій, продуктів;

- підготовка фахівців;

- формуванні інформаційних баз даних;

- контроль якості інноваційного продукту та його сертифікація;

- юридична підтримка інноваційної та інвестиційної діяльності.

Підсумком діяльності Центру $\epsilon$ створення готового до впровадження у виробництво технологічного рішення, що відповідає технічним завданням підприємств залізничного транспорту, замовника, підтвердженого наявністю дослідної партії продукту і супроводжуваного повним пакетом технологічної документації. Характерними особливостями ІМЦІТ повинно стати: наявність сильних зв'язків і інтеграції 3 іноземними партнерамиспоживачами на рівні технологіі; міноритарна участь в капіталі партнерів; висока наукова репутація команди на міжнародному рівні.

Висновки. Підсумовуючи, слід зазначити, що впровадження інжинірингу шляхом створення Інжинірингомаркенингового центру інноваційних технологій ПАТ «Українська залізниця» $€$ дієвим механізмом активізації інноваційно-інвестиційного потенціалу підприємств залізничного транспорту та їх техніко-технологічного розвитку. Він відіграє роль координатора технологічного розвитку та модернізації підприємств, в тому числі рішення таких задач, як уніфікація придбаного устаткування, зниження витрат на його обслуговування.
Формування ІМЦІТ дозволить отримати наступні вигоди:

для ПАТ «Українська залізниця», їх філій, підприємств залізничного транспорту та інших замовників інжинірингових послуг:

- впровадження інноваційних технологій в виробничий процес;

- розвиток інноваційноінвестиційного потенціалу підприємства;

- виробництво інноваційного

продукту, послуг;

- впровадження організаційних,

управлінських інновацій;

- підвищення рівня техніко-

технологічного розвитку;

- нарощення конкурентних переваг на основі інноваційного розвитку, технікотехнологічного розвитку, підвищення рівня конкурентоспроможності підприємств;

для наукових та науково-виробничих підприємств та організацій:

- реалізація науково-дослідних робіт на підприємствах залізничного транспорту;

- комерціалізація інноваційної діяльності, отримання доходу від інноваційної, науково-дослідної діяльності;

- напрацювання практичного досвіду та підвищення рівня кваліфікації працівників;

для виробничих підприємств залізничного транспорту, задіяних у виробництві тестових зразків та інноваційного продукту проміжного значення:

- оновлення техніко-технологічної бази підприємств;

- активізація інноваційного

потенціалу;

- підвищення кваліфікації

персоналу;

- отримання доходу від

виробництва інноваційного продукту;

- завоювання нових ринків.

Загальний очікуваний ефект від організації ІМЦТ, перш за все, повинен принести наступні результати: 
1) зниження вартості дослідно- № 48. - С. 55-59.

конструкторських робіт;

2) технологія «під ключ» - проект виробництва + сертифікований продукт;

3) прискорення

процесів

впровадження інновацій на підприємствах залізничного транспорту і виведення нових продуктів на ринок;

4) завершення цілісності системи впровадження і комерціалізації інноваційних проектів від ідеї до виробництва;

5) інтеграція 3 елементами інноваційної інфраструктури залізничної галузі;

6) залучення

інноваційного потенціалу підприємств залізничного транспорту;

7) підготовка

висококваліфікованих кадрів.

\section{ПЕРЕЛІК ВИКОРИСТАНИХ ДЖЕРЕЛ}

\section{1. Дикань В.Л.}

Основи логістичної інтеграції при формуванні логістичних систем через утворення територіально-промислового кластера / В.Л. Дикань // Міжнародний технікоекономічний журнал «Українські залізниці», липень 2014. -№9(15). - С.23-26.

2. Дикань В.Л. Забезпечення ефективності інноваційної діяльності підприємств залізничного транспорту: монографія / В.Л. Дикань, В.О. Зубенко. Харків: УкрДАЗТ, 2008. - 194 с.

3. Дикань В.Л. Підвищення інвестиційно-інноваційного потенціалу промислових підприємств залізничного транспорту в умовах інтеграційних процесів / В.Л.Дикань, М.І.Данько, Л.Л. Калініченко - Монографія. Харків: УкрДАЗТ, 2010. - 167 с.

4. Дикань В.Л. Подходы к управлению инновационным развитием железнодорожного транспорта Украины / В.Л.Дикань, Ю.А.Рыжова // Вісник економіки транспорту і промисловості. Збір наук. праць. - Харків, УкрДАЗТ, 2014. -
5. Зубенко В.О. Забезпечення ефективності інноваційної діяльності на підприємствах залізничного транспорту / В.О. Зубенко, Л. Коник // Вісник економіки транспорту i промисловості (збірник науково-практичних статей), Харків УкрДУЗТ, 2015. - №49. - С.177-181.

6. Корінь М.В. Концепція створення логістично-інформаційноінноваційно-маркетингового центру «ПРОМЗАЛІННОВАТИКА» / М.В. Корінь // Вісник економіки транспорту та промисловості. - 2012. - № 39. - С. 239-245.

7. Назаренко І.Л. Розвиток раціоналізаторської діяльності як складової інноваційної діяльності на залізничному транспорті / І.Л. Назаренко // Вісник економіки транспорту i промисловості - №40. - 2012. - С. 276 282.

8. Полякова О.М. Світовий досвід формування транспортнологістичних кластерів / О.М. Полякова // Збірник наукових праць Державного економіко-технологічного університету транспорту: Серія «Економіка i управління». - Вип. 28. - К.: ДЕТУТ, 2014. - C. 14-21.

9. Полякова О.М. Проблеми i напрями комерціалізації наукових розробок та інноваційної діяльності в Україні [Текст] / О. М. Полякова // Вісник економіки транспорту і промисловості. 2016. - №54. - C.338-344.

10. Толстова А.В. Модель організаційної структури управління конгломератом «Нноваційнотехнологічний центр розвитку транспортної системи України» / А.В. Толстова // Вісник Харківського національного аграрного університету: збірник наукових праць. Харків: ХНАУ, 2010. - Вип. 10, Серія: «Економічні науки». - С. 270-279.

11. Арсланов В.А. Инжиниринговые центры как фактор вхождения региона в глобальную производственную кооперацию / В.А. Арсанов и др. // Весник 
экономики, права и социологии. - 2014. №4. - С. 7-12.

12. Грибовский А.В Инновационнотехнологические центры как субъект инновационной инфраструктуры Росийской Федерации [Электронный ресурс]/ А.В. Грибовский. - Режим доступа: http://cyberleninka.ru/article/n/.

13. Зайцев А.В. Особености функционирования высокотехнологического предприятия в инновационной экономике / А.В. Зайцев // Вопросы инновационной экономики. - 2014. - №1. C.21-35

14. Краскевич В.С. Фінансовий інжиніринг як інструмент інноваційної діяльності в інвестиційних проектах / В.С. Краскевич, А.В. Селіванова // Математичні машини і системи, 2016. - № 1. - С.71-78.

15. Кудашов В.И. Инжиниринговые центры важнейшая составляющая инновационной инфраструктуры Беларуси /
В.И. Кудашов, Е.О. Пищало //Экономика и управление. - 2016. - №3(47). - С.35-40.

16. Лифанов И.Д. Специфика и перспективы развития инжиниринговых услуг в инновационной сфере / И.Д. Лифанов, А.И. Шинкевич // Российское предпринимательство. - 2014. №19(265). - С.16-27.

\section{7. Ситник}

О. Б. Досвід інжинірингової діяльності в сучасному економічному просторі / О. Б. Ситник // Економіка та управління підприємствами машинобудівної галузі: проблеми теорії та практики. - 2013. - № 4 (24). - С.104-116

18. Чекмачев И.Ю. Инжиниринговый центр как элемент инновационной инфраструктуры региона / И.Ю.Чекмачев, Е.В. Иода // Социально-экономические явления и процессы. - 2014. - Т. 9. - № 9 - С. 84-95.

\title{
СИСТЕМНИЙ ПІДХІД ДО ФОРМУВАННЯ СТРАТЕГІЇ ЗАБЕЗПЕЧЕННЯ ЕКОНОМІЧНОЇ БЕЗПЕКИ ОБОРОННОЇ ПРОМИСЛОВОСТІ УКРАЇНИ В УМОВАХ ЄВРОІНТЕГРАЦІї
}

\author{
Аванесова Н.Е., к.е.н., професор (ХНУБА)
}

\begin{abstract}
Досліджено теоретичні підходи щзодо застосування системного підходу до формування стратегії забезпечення економічної безпеки оборонної промисловості України в умовах євроінтеграції. Доведено, щуо головним стратегічним напрямом національної безпеки та сутнісним орієнтиром зовнішньої політики Украӥни $\epsilon$ інтеграчія у європейські структури, включаючи й структури безпеки. В умовах дотримання багатовекторності зовнішньої політики наш принциповий європейський вибір зумовлюється не сьогоденною кон'юнктурою, а довготерміновими національними інтересами. Зроблено висновок, щзо європейська інтеграція означає зміцнення національної безпеки та безпеки громадян, адже вона виключає застосування сили як методу вирішення залагоджування суперечностей, сприяе стабільності у відносинах з усіма сусідами.
\end{abstract}

Ключові слова: національна безпека, економічна безпека, євроінтеграція, глобалізаційні тенденції, оборонна промисловість 